\title{
PENERIMAAN KONSUMEN TERHADAP LIQUID BODY SOAP EKSTRAK TEMBAKAU DAN ANALISIS HARGA POKOK PRODUKSINYA
}

Acceptence of Consumers to Liquid Body Soap of Tobacco Extracts and Its Product Price Analysis

\author{
Andi Eko Wiyono ${ }^{1) *}$, Winda Amiliaa ${ }^{1)}$, Ida Bagus Suryaningrat ${ }^{1)}$ \\ ${ }^{1)}$ Prodi Teknologi Industri Pertanian, Fakultas Teknologi Pertanian, Universitas Jember \\ Jalan Kalimantan No. 37 Kampus Bumi Tegal boto, Jember, 68121 \\ *Korespondensi Penulis: andi.eko85@yahoo.co.id
}

\begin{abstract}
Liquid body soap is one of the soap products made from a mixture of oil and alkali in liquid form. Addition of tobacco extracts produces liquid body soap which has new characteristics. The existence of tobacco waste extracts can affect the level of consumer acceptance. The level of acceptance of panelists can be measured using hedonic testing. The purpose of this study was to determine the effect of adding tobacco waste extract to the reception of liquid body soap sensory quality attributes and calculating the cost of production. This research was conducted in two steps. The first stage was intended to determine the best formula based on panelists' acceptance. The design that has been used was the single factor Complete Random Design. The factors used in this study were variations in tobacco extract as much as 5\%, 10\%, and $15 \%$. In the next stage, the cost of production was analyzed. The results showed that the addition of tobacco waste extract had no significant effect on panelists' acceptance of the sensory quality attributes of liquid body soap. The best treatment was obtained from the addition of tobacco waste extract as much as 5\%. The cost of producing liquid body soap was $R p$. 9.075,44. Consecutive total costs/ year, selling price, annual profit., and R / C ratio was Rp. 984.023.244,-; Rp. 11.000, -; Rp. 208.673.756,-; and 1,21.
\end{abstract}

Keywords: panelists, tobacco extracts, sensory quality, cost of production

\section{PENDAHULUAN}

Tingkat penerimaan konsumen terhadap suatu produk dapat diukur dengan pengujian mutu sensoris menggunakan alat indra. Pengujian dengan alat indra dikenal dengan uji organoleptik. Uji organoleptik merupakan kesan mutu oleh sekelompok orang yang disebut dengan panelis. Panelis adalah sekelompok orang yang bertugas menilai sifat atau kualitas bahan berdasarkan kesan subyektif. Soekarto (1985) mengelompokkan panelis ke dalam enam kelompok, yaitu panelis pencicipan perorangan, panelis pencicipan terbatas, panelis terlatih, panelis agak terlatih dan, panelis konsumen.

Pada produk agroindustri yang terkait dengan mutu organoleptik, kajian sensoris sangat penting untuk dilakukan. Sebaik apapun pengemasan dilakukan ataupun seefektif mungkin bahan aktif yang dikandung suatu produk, apabila secara organoleptik tidak disukai maka produk tersebut tidak akan diminati konsumen. Oleh karena itu, selera manusia sangat menentukan dalam penerimaan dan menilai suatu produk. Barang yang direspon secara positif oleh indera manusia karena menghasilkan kesan subjektif yang menyenangkan dan memuaskan harapan konsumen dikatakan memiliki kualitas sensoris yang tinggi (Setyaningsih et al., 2010). Begitu pula pada pengembangan produk sabun mandi seperti liquid body soap. Produk tersebut diharapkan mendapatkan respon yang positif dari konsumen.

Liquid body soap tergolong dalam produk komersial yang banyak dikenal oleh masyarakat. Liquid body soap 
merupakan golongan sabun mandi cair yang mampu membersihkan dan melindungi kulit. Menurut Widyasantai et al. (2017), salah satu jenis sabun yang saat ini banyak diproduksi karena penggunaanya lebih praktis dan bentuk yang menarik dibandingkan bentuk sabun lain adalah liquid body soap. Kelebihan liquid body soap jika dibandingkan dengan sabun mandi padat yakni mudah dibawa, mudah disimpan, tidak mudah rusak atau kotor, dan penampilan kemasan yang eksklusif. Namun demikian, untuk meningkatkan penerimaan konsumen terhadap sabun mandi cair tersebut tidak cukup hanya dengan mengandalkan pamor yang sudah ada, akan tetapi perlu dilakukan sentuhan lain. Salah satunya dapat dilakukan dengan menambahkan bahan alami sebagai antibakteri yang aman bagi kesehatan.

Sabun mandi antikuman yang dijumpai sebagian mengandung bahanbahan kimia yang dapat mengganggu kesehatan. Menurut Putra et al. (2016) sediaan sabun mandi antibakteri yang banyak beredar di pasaran mengandung bahan sintetik seperti SLS (Sodium Lauryl Sulfat) dan Tryclosan. Menurut Roslan et al. (2009), penggunaan SLS melebihi konsentrasi yang dianjurkan akan bersifat karsinogenik dan dapat menyebabkan terjadinya iritasi epidermis serta denaturasi rantai polipeptida suatu molekul protein sehingga merubah struktur protein.

Berdasarkan hal tersebut dilakukan kajian penerimaan panelis guna mengetahui pengaruh penambahan ekstrak tembakau terhadap penerimaan atribut mutu liquid body soap. Selain itu, juga dilakukan penentuan harga pokok produksi agar mendapatkan keuntungan pada proses produksinya dalam skala industri rumah tangga.

\section{METODE PENELITIAN}

Alat dan Bahan

$\begin{array}{ccc}\text { Alat yang digunakan } & \text { adalah } \\ \text { peralatan } & \text { gelas, } & \text { neraca, } \\ \text { spatula, }\end{array}$ erlenmeyer, kompor, kuesioner, alat tulis, dan perangkat komputer. Bahan baku yang digunakan dalam penelitian ini adalah minyak nabati (minyak kelapa dan minyak sawit) dan daun tembakau sisa jenis Kasturi. Daun tembakau sisa diperoleh dari Kecamatan Ambulu Kabupaten Jember. Bahan lain yang digunakan adalah $\mathrm{KOH}$ dan akuades.

\section{Tahapan Penelitian}

\section{Pembuatan Ekstrak Tembakau}

Ekstraksi tembakau menggunakan metode yang dilakukan oleh Rizkayanti (2017) dengan modifikasi, yakni dengan teknik dekok. Dekok adalah ekstraksi dengan pelarut air pada temperatur $90^{\circ} \mathrm{C}$ selama 30 menit. Sebanyak 30 g serbuk kering dimasukkan ke dalam gelas kimia dan ditambahkan akuades hingga $300 \mathrm{~mL}$ sampai seluruh serbuk terendam. Selanjutnya dipanaskan secara tidak langsung dalam erlenmeyer selama 30 menit. Waktu 30 menit dihitung setelah suhu dalam gelas kimia telah mencapai $90^{\circ} \mathrm{C}$.

\section{Pembuatan Liquid Body Soap}

Minyak kelapa dan minyak sawit ditempatkan di dalam suatu tempat dan dipanaskan. Pemanasan dilakukan hingga minyak bersuhu $70-90^{\circ} \mathrm{C}$. Selanjutnya dimasukkan larutan $\mathrm{KOH}$ dan diaduk hingga homogen, selama 30-60 menit sampai pada fase trace. Pemanasan dilanjutkan \pm 3 jam sampai warna bening dan mudah dicairkan. Base soap yang terbentuk dicairkan dengan akuades. Akuades panas diberikan secara bertahap, pencairan berlangsung minimal 3 jam. Penambahan ekstrak tembakau pada saat kondisi suhu antara $50-60^{\circ} \mathrm{C}$. 


\section{Rancangan Percobaan}

Rancangan percobaan dalam penelitian ini menggunakan Rancangan Acak Lengkap (RAL) faktor tunggal dengan tiga perlakuan dan tiga kali ulangan. Perlakuan tersebut meliputi A0 adalah liquid body soap dengan ekstrak tembakau 5\%, A1 adalah liquid body soap dengan ekstrak tembakau $10 \%$, dan A2 adalah liquid body soap dengan ekstrak tembakau $15 \%$.

\section{Metode Analisis}

Analisis data pada penelitian ini meliputi uji penerimaan konsumen dan analisis harga pokok produksi (HPP). Uji penerimaan menggunakan metode Setyaningsih et al. (2015) yang dimodifikasi. Uji penerimaan digunakan untuk mengetahui penerimaan panelis terhadap ketiga formulasi liquid body soap tembakau. Pada uji penerimaan, sebanyak 30 panelis tidak terlatih dengan rentang usia 15-55 tahun diminta penilaiannya terhadap parameter penerimaan dengan atribut warna, aroma, kekentalan, dan kesan pemakaian. Angka yang diperoleh kemudian ditransformasikan dalam skala yaitu: satu (1) sangat tidak suka, dua (2) tidak suka, tiga (3) netral, empat (4) suka, dan lima (5) sangat suka. Data yang diperoleh dianalisis menggunakan analisa chi-square dengan selang kepercayaan 5\% $(\alpha=0.05)$. Pemilihan perlakuan terbaik menggunakan metode indeks efektivitas dengan prosedur pembobotan (De Garmo et al., 1984).

Penentuan HPP menggunakan metode full costing (Bustami dan Nurlela, 2007). Selain itu juga dilakukan penentuan harga jual, analisis biaya, $\mathrm{R} / \mathrm{C}$ rasio, dan profit. Data hasil perhitungan dinalisis secara deskriptif kuantitatif (Suryabrata, 2011). Data yang diperoleh diolah menggunakan microsoft excel dan hasil pengolahan disajikan dalam bentuk tabel.

\section{HASIL DAN PEMBAHASAN}

\section{Tingkat Penerimaan Panelis Terhadap Liquid Body Soap Ekstrak Tembakau Penerimaan Warna}

Salah satu parameter penting dalam uji organoleptik adalah warna, hal ini terkait dengan daya tarik, tanda pengenal, dan atribut mutu. Diantara sifat-sifat produk, warna memberikan respon paling cepat terhadap kesan suka atau tidak disukai. Menurut Wahono (2006), rangsangan cahaya yang memasuki lensa mata akan diterima oleh retina akan diteruskan ke otak melalui syaraf-syaraf mata yang ada sebagai sensasi. Di otak sensasi ini akan dirubah menjadi persepsi dan pada akhirnya akan dirubah menjadi respon. Respon penerimaan panelis terhadap atribut mutu warna pada liquid body soap ekstrak tembakau disajikan pada Gambar 1.

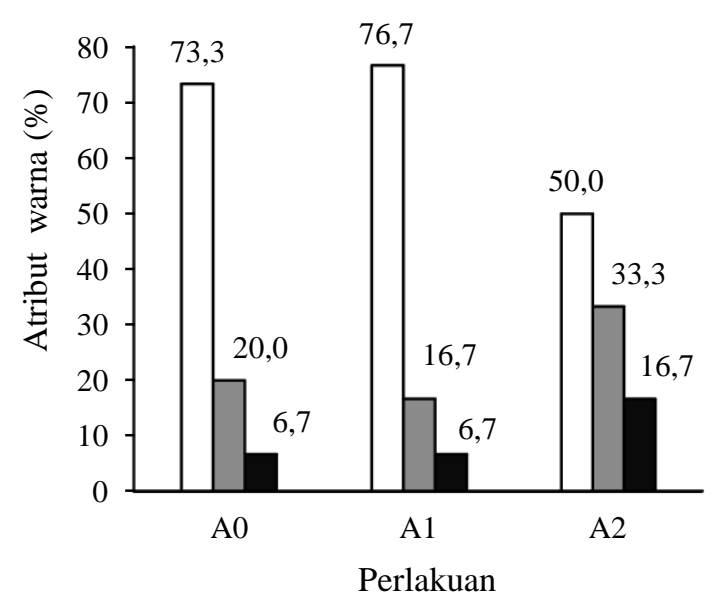

Gambar 1. Persentase tingkat penerimaan atribut mutu warna liquid body ekstrak tembakau pada tingkat penerimaan panelis suka-sangat suka ( $\square$ ); cukup suka ( $\square)$; tidak suka-sangat tidak suka ( $\square)$

Liquid body soap ekstrak tembakau dengan penilaian suka hingga sangat suka tertinggi pada atribut warna adalah perlakuan A1 yakni liquid body soap dengan ekstrak tembakau $10 \%$ sebesar $76,7 \%$. Tingkat penerimaan panelist terhadap atribut mutu warna dengan 
penilaian suka hingga sangat suka terendah pada perlakuan A2 yakni liquid body soap dengan ekstrak tembakau $15 \%$ sebesar $50 \%$. Warna liquid body soap ekstrak tembakau pada berbagai perlakuan cenderung coklat keemasan, semakin banyak ekstrak yang ditambahkan intensitas warna coklatnya semakin tinggi. Menurut Alegantina (2017), warna ekstrak etanol tembakau berwarna hitam sedangkan warna ekstrak air tembakau berwarna coklat (Naufalin et al., 2011).

Hasil pengujian penerimaan panelis pada warna liquid body soap ekstrak tembakau menunjukkan bahwa pada perlakuan ekstrak tembakau tidak berpengaruh nyata pada taraf 5\% terhadap kesukaan warna. Nilai chi square perhitungan lebih kecil dari nilai chi square tabel 0,05 yaitu 5,90<26,296. Kondisi tersebut menggambarkan bahwa kesukaan panelis terhadap warna tidak dipengaruhi oleh penambahan ekstrak tembakau.

\section{Penerimaan Aroma}

Aroma merupakan atribut sensoris yang dapat menggambarkan rasa dari suatu produk merkipun belum dikonsumsi. Aroma juga dapat menentukan komponen bahan yang digunakan dalam membuat produk tersebut. Akan tetapi, Setyaningsih et al. (2010) menyatakan bahwa bau atau aroma merupakan sifat sensoris yang paling sulit untuk diklasifikasikan dan dijelaskan karena ragamnya yang begitu besar, sehingga kadang diperlukan usaha dengan menggolongkan bau berdasarkan struktur kimia, ukuran, bentuk molekul dan gugus fungsional.

Respon penerimaan panelis terhadap atribut aroma liquid body soap ekstrak tembakau secara lengkap pada Gambar 2. Tingkat penerimaan atribut aroma tertinggi pada kriteria cukup suka. Liquid body soap ekstrak tembakau dengan penilaian cukup suka tertinggi pada atribut aroma adalah perlakuan A0 yakni liquid body soap dengan ekstrak tembakau 5\% sebesar $80 \%$
Tingkat penerimaan panelis terhadap atribut mutu aroma pada perlakuan A1 dan A0 sama yakni sebesar 70\%. Liquid body soap ekstrak tembakau dengan penilaian suka dan sangat suka tertinggi pada atribut mutu aroma adalah perlakuan A1, namun persentasenya tergolong kecil yakni $23 \%$. Kecilnya nilai penerimaan panelis terhadap atribut mutu aroma disebabkan karena aroma tembakau belum signifikan. Aroma sabun lebih dominan dibandingkan aroma tembakau pada semua perlakuan.

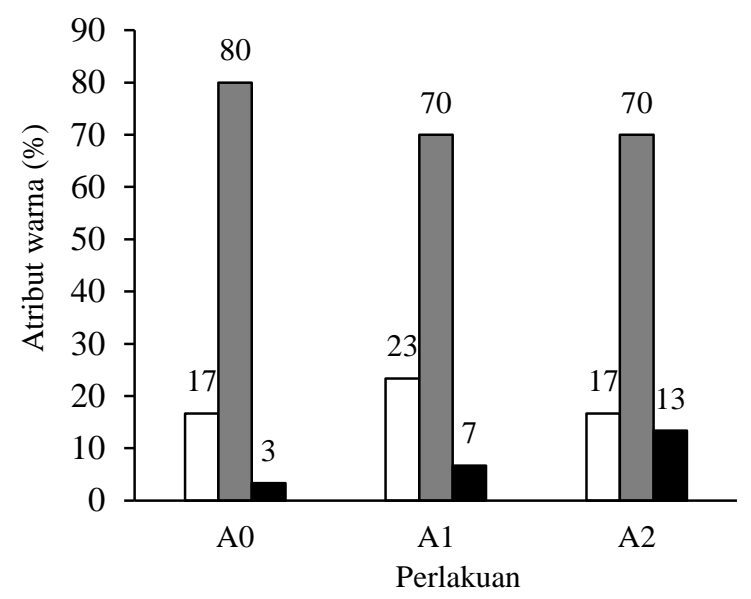

Gambar 2. Persentase tingkat penerimaan atribut mutu aroma liquid body soap ekstrak tembakau pada tingkat penerimaan panelis suka-sangat suka $(\square)$; cukup suka ( $\square$ ); tidak suka-sangat tidak suka (ם)

Hasil perhitungan chi square atribut aroma menunjukkan nilai chi square perhitungan lebih kecil dari nilai chi square tabel 0,05 yaitu $2,73<26,29$. Hasil analisis chi square menunjukkan bahwa penambahan ekstrak tembakau 5\%, 10\%, dan $15 \%$ memberikan pengaruh yang tidak nyata terhadap penerimaan atribut mutu aroma liquid body soap.

\section{Penerimaan Kekentalan}

Tekstur bersifat kompleks dan terkait dengan stuktur bahan, yang terdiri tiga elemen yaitu: mekanik (kekerasan kekenyalan), geometrik (berpasir, beremah), dan mouthfeel (Berminyak, berair) (Setyaningsih et al. 2010). Tekstur 
bahan cair dapat diistilahkan dengan kekentalan.

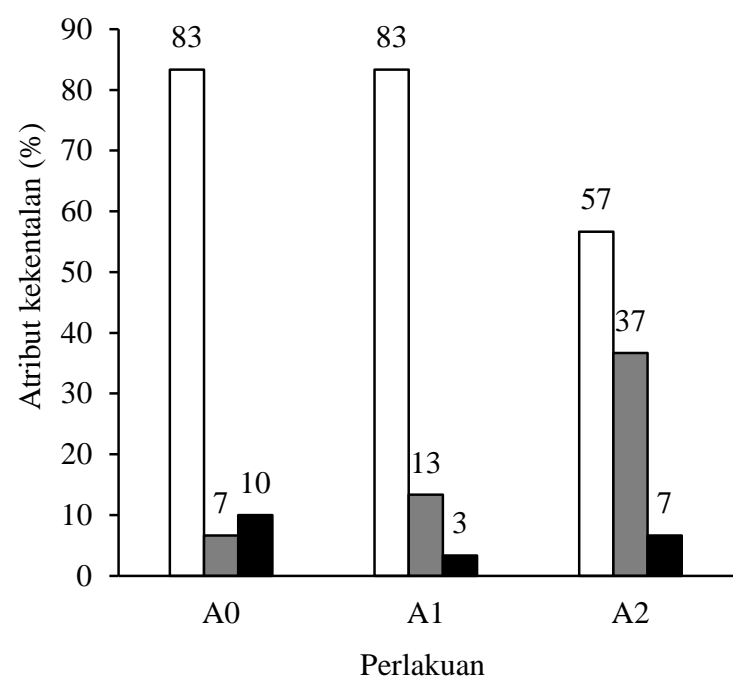

Gambar 3. Persentase tingkat penerimaan atribut mutu kekentalan liquid body soap ekstrak tembakau pada tingkat penerimaan panelis suka-sangat suka ( $\square$ ); cukup suka $(\square)$; tidak sukasangat tidak suka (

Liquid body soap ekstrak tembakau dengan penilaian suka dan sangat suka tertinggi pada atribut mutu kekentalan adalah perlakuan A0 dan A1 yakni sebesar $83 \%$. Tingkat penerimaan panelis terhadap atribut mutu kekentalan pada penilaian suka dan sangat suka terendah pada perlakuan A2 yakni 57\%. Semakin banyak ekstrak yang ditambahkan, menyebabkan viskositas semakin menurun, sehinga kekentalan produk semakin berkurang. Hal tersebut yang menyebabkan penurunan tingkat penerimaan panelis terhadap kesukaan atribut mutu kekentalan liquid body soap ekstrak tembakau. Respon penerimaan panelis terhadap atribut mutu kekentalan secara lengkap pada Gambar 3.

Hasil perhitungan chi square atribut mutu kekentalan menunjukkan nilai chi square perhitungan lebih kecil dari nilai chi square tabel 0,05 yaitu $10,793<26,29$. Hasil analisis chi square menunjukkan bahwa penambahan ekstrak limbah tembakau memberikan pengaruh yang tidak nyata terhadap penerimaan atribut mutu kekentalan liquid body soap ekstrak tembakau.

\section{Penerimaan Kesan}

Rasa kesat menimbulkan kesan pada pemakaian sabun mandi. Kesat yang dimaksud adalah rasa tidak licin atau berminyak ditangan setelah pemakaian Rasa kesat dipengaruh oleh adanya alkali bebas. Semakin banyak alkali bebas menyebabkan rasa kesat semakin tinggi, namun hal tersebut dapat menyebabkan kulit kering (Wijana et al., 2005).

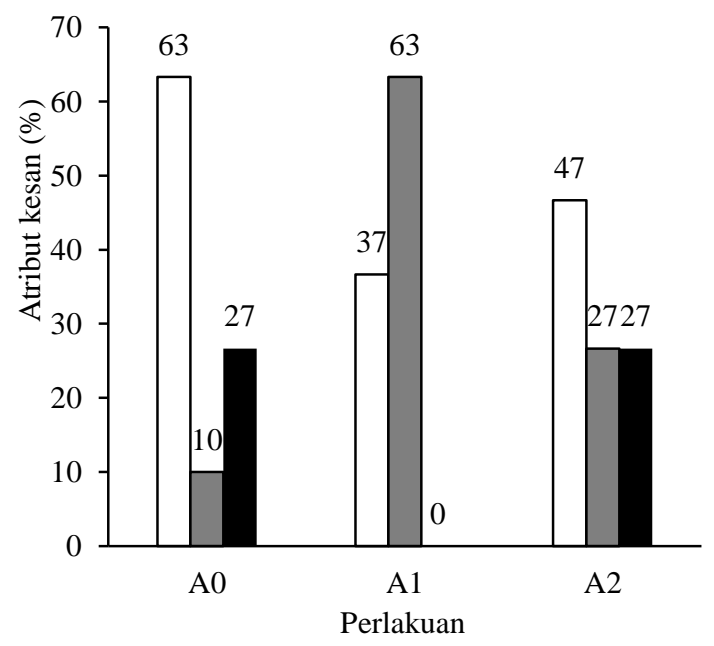

Gambar 4. Persentase tingkat penerimaan atribut mutu kesan liquid body soap ekstrak tembakau pada tingkat penerimaan panelis suka-sangat suka $(\square)$; cukup suka ( $\square)$; tidak suka-sangat tidak suka (ם)

Liquid body soap ekstrak tembakau dengan penilaian suka dan sangat suka tertinggi pada atribut mutu kesan adalah perlakuan A0 yakni liquid body soap dengan ekstrak tembakau 5\% yakni sebesar $63 \%$. Tingkat penerimaan panelis terhadap atribut mutu kesan dengan penilaian suka dan sangat suka terendah pada perlakuan A1 dengan penambahan ekstrak tembakau 15\%, yakni $37 \%$. Respon hasil penerimaan atribut mutu kesan pada liquid body soap ekstrak tembakau secara lengkap pada Gambar 4. 
Hasil pengujian sensoris tingkat penerimaan liquid body soap ekstrak tembakau menunjukkan bahwa penambahan ekstrak tembakau berpengaruh tidak nyata pada penerimaan atribut kesan. Hasil perhitungan chi square atribut aroma menunjukkan nilai chi square perhitungan lebih kecil dari nilai chi square tabel 0,05 yaitu $2,73<26,29$.

\section{Penentuan Perlakuan Terbaik}

Penentuan perlakuan terbaik menggunakan uji efektivitas bertujuan untuk memilih satu perlakuan yang akan dilanjutkan dan dikembangkan pada tahap penelitian berikutnya. Parameter dalam penentuan perlakuan terbaik liquid body soap ekstrak tembakau adalah tingkat penerimaan panelis. Urutan perlakuan yang paling disukai panelis adalah perlakuan A0 diikuti perlakuan A1, dan perlakuan A2. Penambahan ekstrak tembakau 5\% menjadi alternatif perlakuan terbaik. Hasil penilaian alternatif terbaik liquid body soap ekstrak tembakau menggunakan metode indeks efektivitas dengan prosedur pembobotan (De Garmo et al., 1984).

\section{Analisa Biaya dan Harga Pokok Produksi (HPP) Liquid Body Soap Ekstrak Tembakau}

Aspek Teknis dan Teknologi

Teknologi yang diterapkan pada penelitian ini adalah teknologi tepat guna, sehingga mudah dilakukan. Bahan baku yang digunakan adalah bahan alami, sedangkan bahan pembantu yang digunakan adalah $\mathrm{KOH}$ yang tersedia di toko bahan kimia. Kapasitas produksi liquid body soap ekstrak didasarkan atas penggunaan total bahan sebanyak $18 \mathrm{~kg}$ atau base soap sebanyak 17,86 kg yang terbagi dalam dua kali pembuatan base soap setiap produksi. Peralatan yang digunakan yakni peralatan rumah tangga dengan rendemeen based soap 80,07\%.
Komposisi bahan liquid body soap ekstrak tembaku dapat dilihat pada Tabel 1.

Pencairan base soap dilakukan dengan menambahkan akuades panas secara bertahap. Hasil yang diperoleh berupa liquid body soap sebagai prototipe. Prototipe yang dianalisis dirancang sebagai prototipe $\mathrm{A}$, prototipe $\mathrm{B}$, dan prototipe $\mathrm{C}$, yakni berturut-turut liquid body soap ekstrak tembakau dengan botol kemasan biasa tanpa essential oil, liquid body soap ekstrak tembakau dengan botol pump tanpa essential oil, dan liquid body soap ekstrak tembakau dengan botol pump ditambah essential oil. Prototipe liquid body soap ekstrak tembakau disajikan pada Gambar 5.

Berdasarkan pengamatan organoleptik, diketahui bahwa liquid body soap ekstrak tembakau tanpa essential oil memiliki hasil pengamatan organoleptik yang sama antara warna dan konsistensinya. Perbedaan nampak pada hasil pengamatan aroma. Aroma liquid body soap ekstrak tembakau dengan essential oil lebih tajam, dengan aroma tembakau dan vanila yang segar. Hasil pengamatan organoleptik terhadap liquid body soap ekstrak tembakau dengan dan tanpa essential oil disajikan pada Tabel 2 dan Tabel 3.

Tabel 1. Komposisi liquid body soap ekstrak tembakau

\begin{tabular}{lcc}
\hline \multirow{2}{*}{ Bahan } & \multicolumn{2}{c}{ Skala } \\
\cline { 2 - 3 } & Laboratorium & $\begin{array}{c}\text { Industri Rumah } \\
\text { Tangga }\end{array}$ \\
\hline $\begin{array}{l}\text { Minyak } \\
\text { Kelapa (g) } \\
\text { Minyak }\end{array}$ & 111 & 2880 \\
$\begin{array}{l}\text { Sawit (g) } \\
\text { KOH (g) }\end{array}$ & 48 & 6660 \\
Akuades (g) & 105 & 2160 \\
\hline
\end{tabular}


Tabel 2. Pengamatan organoleptik terhadap liquid body soap ekstrak tembakau tanpa essential oil

\begin{tabular}{lc}
\hline Parameter & Deskripsi \\
\hline Aroma & Khas sabun \\
Warna & Coklat terang \\
Konsistensi & Kental \\
\hline
\end{tabular}

Tabel 3. Pengamatan organoleptik terhadap liquid body soap ekstrak tembakau dengan essential oil

\begin{tabular}{|c|c|}
\hline Parameter & Deskripsi \\
\hline Aroma & $\begin{array}{l}\text { Khas sabun dengan aroma } \\
\text { segar tembakau dan vanilla }\end{array}$ \\
\hline Warna & Coklat terang \\
\hline Konsistensi & Kental \\
\hline
\end{tabular}

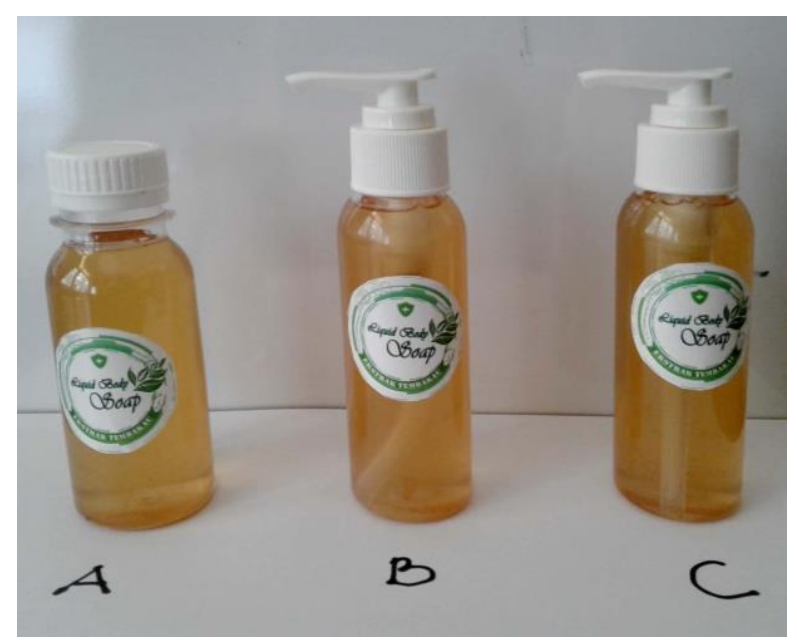

Gambar 5. Prototipe liquid body soap ekstrak tembakau yaitu liquid body soap ekstrak tembakau dengan botol kemasan biasa tanpa essential oil (A), liquid body soap ekstrak tembakau dengan botol pump tanpa essential oil (B), dan liquid body soap ekstrak tembakau dengan botol pump ditambah essential oil (C)

Fitur produk liquid body soap ekstrak tembakau pada penelitian ini berwujud cairan yang kental, beraroma khas sabun dengan sentuhan aroma tembakau, dan berwarna coklat terang keemasan. Stiker atau label kemasan produk pada botol dibuat dengan warna hijau identik dengan daun tembakau.
Stiker memuat informasi tentang identitas liquid body soap tembakau serta menambah nilai estetika agar lebih menarik minat konsumen. Ukuran stiker primer berdiameter $4 \mathrm{~cm}$. Jenis kemasan yang digunakan adalah botol plastik 100 $\mathrm{mL}$.

\section{Analisis Biaya}

Pada produksi liquid body soap ekstrak tembakau diperlukan biaya investasi yang dikeluarkan pada awal umur proyek secara keseluruhan. Barang-barang investasi akan habis dipakai jika umur ekonomisnya telah habis sehingga barangbarang tersebut harus mengalami reinvestasi. Biaya produksi yang dibutuhkan dalam produksi liquid body soap meliputi biaya tetap (fixed cost) dan biaya tidak tetap (variable cost). Biaya tetap adalah biaya yang tidak dipengaruhi oleh banyak maupun sedikitnya produk. Biaya tidak tetap adalah biaya yang besar kecilnya tergantung pada sedikit atau banyaknya produk.

Tabel 4 dan Tabel 5 menunjukkan bahwa jumlah biaya investasi untuk produksi liquid body soap ekstrak tembakau pada ke tiga skenerio yang dirancang adalah sama, yakni Rp. 32.735.500,-. Total biaya tetap dan tidak tetap berturut-turut prototipe A, prototipe $\mathrm{B}$, dan prototipe $\mathrm{C}$ adalah $\mathrm{Rp}$. 558.703.324,-; Rp. 775.557.324,-; dan Rp. 984.023.244,-. Dari nilai tersebut diketahui bahwa perbedaannya sangat mencolok. Hal ini dikarenakan pada skenario $\mathrm{C}$ menggunakan essential oil dan pum botol. Harga essential oil cukup mahal namun masih terjangkau, dan harga pump botol $100 \mathrm{~mL}$ lebih mahal dibanding botol biasa. 
Tabel 4. Analisa biaya dan HPP prototipe A dan B

\begin{tabular}{lrr}
\hline \multirow{1}{*}{ Rincian } & \multicolumn{2}{c}{ Nilai } \\
\cline { 2 - 3 } $\begin{array}{l}\text { Total biaya } \\
\text { investasi }\end{array}$ & Rp. 32.735.500,- & Rp. 32.735.500,- \\
Total biaya & Rp. 558.703.324,- & Rp. 775.557.324,- \\
tetap dan & & \\
tidak tetap/ & & \\
tahun & & Rp. 7.152,81 \\
HPP & Rp. 5.152,81 & Rp.8.600,- \\
Harga jual & Rp. 6.200,- & \\
Keuntungan & & Rp. 156.914.876,- \\
/ tahun & Rp. 113.544.076,- \\
R/C rasio & 1,20 & 1,20 \\
\hline
\end{tabular}

Tabel 5. Analisa biaya dan HPP prototipe C

\begin{tabular}{lr}
\hline \multicolumn{1}{c}{ Rincian } & \multicolumn{1}{c}{ Nilai } \\
\cline { 2 - 2 } Total biaya investasi & Rp. $32.735 .500,-$ \\
Total biaya tetap dan & Rp. $984.023 .244,-$ \\
tidak tetap/ tahun & \\
HPP & Rp. 9.075,44 \\
Harga jual & Rp. $11.000,-$ \\
Keuntungan/ tahun & Rp. 208.673.756,- \\
R/C rasio & \\
\hline
\end{tabular}

\section{Harga Pokok Produksi (HPP) dan Harga} Penjualan

Harga pokok produksi merupakan semua biaya produksi yang dikeluarkan untuk memproduksi suatu barang atau jasa selama peride tertentu. Harga pokok produksi digunakan sebagai dasar bagi perusahaan dalam menentukan harga jual. Berdasarkan perhitungan dengan berat bersih tiap botol sebesar $100 \mathrm{~mL}$ dengan skenario yangdirancang diketahui bahwa harga pokok produksi (HPP) berturut-turut berturut-turt skenario $\mathrm{A}$, skenario $\mathrm{B}$, dan skenario $C$ adalah Rp. 5.152,81; Rp. 7.152,81; dan Rp. 9.075,44. HPP juga dipengaruhi oleh faktor biaya. Menurut Mulyadi (2010), HPP melalui pendekatan full costing merupakan metode penentuan harga pokok produksi dengan perhitungan semua unsur biaya produksi yang banyak dipakai oleh manajer perusahaan untuk pengambilan keputusan dalam jangka panjang.

Penentuan harga jual produk menggunakan metode cost plus pricing. Menurut Fitrah dan Retnani (2014), metode cost plus pricing merupakan metode penentuan harga jual normal yang dihitung berdasarkan biaya produksi dan biaya penjualan serta tambahan markup sesuai yang diharapkan. Liquid body soap ekstrak tembakau tersebut dijual dengan kisaran harga masing-masing perbotol yang berisi $100 \mathrm{~mL}$ sebesar Rp. 6.200,-; Rp. 8.600,-; dan Rp. 11.000,-. Persentase markup adalah sama yakni $21 \%$.

\section{Proyeksi Pendapatan dan Keuntungan}

Penerimaan atau pendapatan pada produksi diperoleh dari penjualan produk. Nilai pendapatan tergantung dari jumlah produksi dan harga jualnya. Keuntungan diperoleh dari selisih antara total pendapatan dan total biaya produksi. Keuntungan per tahun yang diperoleh pada masing-masing skenario berturut-turut sebesar Rp. 113.544.076,-; Rp. 156.914.876,-; dan Rp. 208.673.756,-. Hal ini tentunya sangat menguntungkan, mengingat tembakau sisa bernilai ekonomis rendah.

\section{R/C Rasio}

Reveniew Cost Ratio (R/C Rasio) adalah suatu pengujian analisa kelayakan dengan perbandingan antara total pendapatan dengan total biaya yang dikeluarkan. Kriterian yang digunakan dalam analisis ini adalah apabila nilai $\mathrm{R} / \mathrm{C}$ $>1$ maka usaha tersebut dikatakan untung dan layak untuk diusahakan, karena besarnya pendapatan lebih besar dari besarnya biaya yang dikeluarkan, dan sebaliknya (Asnidar, 2017).

Hasil perhitungan $\mathrm{R} / \mathrm{C}$ rasio berturutturut pada skenario $\mathrm{A}, \mathrm{B}$, dan $\mathrm{C}$ menunjukkan 1,$20 ; 1,20$; dan 1,21. Hasil tersebut menunjukkan bahwa secara finansial produksi liquid body soap ekstrak tembakau layak untuk diijalankan. 
Menurut Suratiyah (2015), apabila R/C rasio lebih besar dari 1, maka usaha tersebut menguntungkan.

\section{KESIMPULAN}

Penambahan ekstrak tembakau pada liquid body soap berpengaruh tidak nyata terhadap penerimaan warna, aroma, kekentalan, dan kesan. Perlakuan terbaik didapat pada liquid body soap pada perlakuan A0 dengan penambahan ekstrak tembakau sebesar 5\%. Berdasarkan prototipe $\mathrm{C}$ yang dirancang menunjukkan bahwa usaha ini dapat dijalankan dengan harga pokok produksi (HPP) Rp. 9.075,44. Pada mark up sebesar $21 \%$, liquid body soap ekstrak tembakau dijual dengan kisaran harga Rp. 11.000,-. Keuntungan pertahun yang diperoleh Rp. 208.673.756,. Dari perhitungan $\mathrm{R} / \mathrm{C}$ rasio dinyatakan agroindustri liquid body soap ekstrak tembakau layak untuk dijalankan dengan nilai $\mathrm{R} / \mathrm{C}$ rasio 1,21 .

\section{UCAPAN TERIMA KASIH}

Ucapan terima kasih ditujukan kepada Universitas Jember atas Hibah Internal Sumberdana DIPA Universitas Jember yang telah mendukung secara finansial terlaksananya penelitian yang berjudul Formulasi Liquid Body Soap Berbasis Limbah Tembakau untuk Mendukung Agroindustri Berkelanjutan pada Tahun Anggaran 2018.

\section{DAFTAR PUSTAKA}

Aligentina, S. 2017. Penetapan kadar nikotin dan karakteristik ekstrak daun tembakau (Nicotina tabacum, L.). Jurnal Penelitian dan Pengembangan Pelayanan Kesehatan, 1 (2): 113-119.

Asnidar dan Asrida. 2017. Analisis kelayakan usaha home industri kerupuk opak di Desa Paloh Meunasah Dayah Kecamatan Muara Satu Kabupaten Aceh Utara. Jurnal Sains Pertanian, 1 (1): 39-47.
Bustami, B., dan Nurlela. 2007. Akuntansi Biaya. Graha Ilmu, Yogyakarta.

De Garmo, E.P., W.G. Sullivan., dan C.R. Candra. 1984. Engineering Economi. 7th edition. Mc Millan Publ. Co., New York.

Fitrah, R. dan Retnani, E. D. 2014. Penentuan harga jual menggunakan cost plust pricing dengan pendekatan variable costing. Jurnal Agroteknologi, 1 (1): 36-41.

Morrisan. 2012. Metode Penelitian Survey. Kencana Prenadamedia Group, Jakarta.

Mulyadi. 2010. Akuntansi Biaya. Sekolah Tinggi Ilmu Manajemen YKPN, Yogyakarta.

Naufalin, R., Astuti, S. D., dan Wicaksono, R. 2011. Produksi coating antimikroba berbasis lilin alami dan komposit pati dengan senyawa antimikroba ekstrak limbah tembakau untuk penanganan pascapanen buah dan sayuran. Jurnal Litbang Provinsi Jawa Tengah, 9 (2): 160-172.

Putra, R. M., Fahrurroji, A., dan Wijianto, B. 2016. Optimasi formulasi sabun mandi cair ekstrak rimpang jahe merah. Jurnal Teknosains, 5 (2): 81146.

Rizkayanti, Wahid, A., Diah, M., dan Jura, M. R. 2017. Uji aktivitas antioksidan ekstrak air dan ekstrak etanol daun kelor (Moringa Oleifera L.). Jurnal Akademia Kimia, 6 (2): 125-131.

Roslan, A.N., Sunariani, J., dan Irmawati, A. 2009. Penurunan Sensitivitas Rasa Manis Akibat Pemakaian Pasta Gigi yang Mengandung Sodium Lauryl Sulphate 5\%. Jurnal Persatuan Dokter Gigi Indonesia, 58 (2):10-13.

Setyaningsih, D., Apriyantono, A., dan Sari, M. P. 2010. Analisis Sensori untuk Industri Pangan dan Agro. Cetakan I. IPB Press, Bogor.

Soekarto, S.T. 1985. Penilaian Organoleptik untuk Industri Pangan dan Hasil Pertanian. Bhratara Karya Akasara, Jakarta. 
Suratiyah, K. 2015. Ilmu Usaha Tani. Penerbit Swadaya, Jakarta.

Suryabrata. 2011. Metodologi Penelitian. Raja Grafindo Persada, Jakarta.

Wahono, T. 2006. Dasar-Dasar Uji Indrawi. Fakultas Teknologi Pertanian. Universitas Brawijaya Press, Malang.

Widyasanti, A., Qurratu'ain, Y., dan Nurjanah, S. 2017. pembuatan sabun mandi cair berbasis minyak kelapa murni (VCO) dengan penambahan minyak biji kelor (Moringa oleifera Lam). Chimica et Natura Acta, 5 (2): 77 84.

Wijana, S., Mustaniroh, S. A., dan Wahyuningrum, I. 2005. Pemanfaatan minyak goreng bekas untuk pembuatan sabun. Jurnal Teknologi Pertanian, 6 (3): 193202. 